\title{
The choice of mixed marriage among the second generation in France: a life-course approach
}

\author{
Emmanuelle Santelli \\ Université de Lyon. CNRS \\ emmanuelle.santelli@ish-lyon.cnrs.fr \\ Beate Collet \\ Université Paris IV-Sorbonne. GEMASS \\ beate.collet@paris-sorbonne.fr
}

Received: 18-11-2010

Accepted: 09-11-2011

\begin{abstract}
Research on couples with different cultural backgrounds, i.e. couples including persons of migrant descent, has been conducted in France since the 1980s. Researchers currently use the concept 'mixitê' (mixedness), which suggests that the process is a question not only of culture, but also of social group and gender. By calling the couples 'mixed' our aim is to study these questions in all their multi-faceted dimensions.

These couples are 'mixed' not because they are bi-cultural, but because their choice challenges marital norms and group memberships. Against the backdrop of considerations on endogamy and homogamy, we present some key ideas brought to light by 91 in-depth, biographical interviews with 57 women and 34 men, conducted in 2007. Because we compared endogamous and mixed couples, it was possible to identify how the different types of couples reach their marital choices and to what extent they are influenced by cultural, gendered or social factors. These factors are both personal (education level, specific conditions of socialisation and peer groups) and structural (urban segregation or overall social discrimination).
\end{abstract}

Key words: couples; migrant descent; marital relations; endogamy; homogamy; marital choice; family relations; group socialisation; urban segregation; social discrimination.

Resumen. La elección de un matrimonio mixto en la segunda generación en Francia: un enfoque del ciclo vital

El estudio de parejas con diferentes trasfondos culturales, como por ejemplo parejas compuestas por personas de descendencia migratoria, se inició hace tan sólo unos años. Los investigadores suelen utilizar el concepto de mixité (mestizaje), según el cual el proceso de hibridación no sólo es una cuestión de cultura sino también de pertenencia social y de género. Al denominar a las parejas «mixtas» se nos abre la posibilidad de estudiar estas cuestiones a partir de su interdependencia. 
Estas parejas no son mixtas porque sean biculturales, sino porque su elección cuestiona las normas maritales y de pertenencia al grupo. Por ello, en contra de las consideraciones sobre la endogamia y la homogamia, presentamos algunas ideas clave basadas en un trabajo de campo reciente: en el año 2007 realizamos 91 entrevistas biográficas en profundidad a 57 mujeres y 34 hombres. Se compararon parejas endogámicas y mixtas, por lo que fue posible explorar cómo los diferentes tipos de parejas eligen su cónyuge y hasta qué punto intervienen en ello factores culturales, de género y sociales. Se trata de factores tanto personales (nivel de educación, condiciones específicas de socialización y grupos de pares) como estructurales (segregación urbana o discriminación social a escala global).

Palabras clave: parejas; descendientes de migrantes; relaciones matrimoniales; endogamia; homogamia; elección del cónyuge; relaciones familiares; socialización de grupo; segregación urbana; discriminación social.

\section{Summary}

1. Second generation conjugal patterns: a specific mode of couple formation

2. Methods and survey population
3. The process of conjugal choice

4. Family dynamics

Bibliographic references

In France, substantial research was conducted on "mixed couples" — which included immigrants and their children raised in France- in the 1980s and 1990s. As well as distinguishing between quantitative (Muñoz-Perez, Tribalat, 1984; Tribalat, 1996; Neyrand, M'Sili, 1997; Hamel et al, 2010) and qualitative studies (Barbara, 1985; Streiff-Fenart, 1985; Philippe, Varro, Neyrand, 1998), a distinction must also be made between those which consider mixed couples in general (Varro, 2003; Filhon, Varro, 2005; Collet, 2010) and those which focus on specific populations. In the case of France, sociologists have generally centred their attention on populations from the Maghreb and sub-Saharan Africa (Streiff-Fenart, 1989; Rude-Antoine, 1990; Hammouche, 1990; Delcroix, Guyaux, Rodriguez, 1992), while in other European countries interest has focused elsewhere: on the Turkish population in Germany (Strabburger, 2003), on the Indian and Pakistani populations in the United Kingdom, (Shaw, 2001), and more recently on Africans in Spain (Rodriguez-Garcia, 2006). A further distinction must be made concerning the population of interest: while some researchers have looked exclusively at immigrants (Collet, 1996, 1998; Meintel, 2002; Le Gall, 2003; Safi, 2008; Collet, Régnard, 2011), others also include (or focus entirely on) the second generation (Sad Saoud 1985, Santelli, Collet, 2003; Collet, Santelli, 2008, 2012b; Hamel et al., 2010). Indeed, there is growing interest in the marital patterns of persons of immigrant descent, mostly born in France and possessing French nationality. This interest took place firstly for demographic reasons because many of them were of an age to live with a partner or get married and had thus entered the marriage market in France. Secondly, noticing that many couples are formed by partners from the same origins, researchers want 
to understand the reasons for that endogamy. In this context, is it possible to identify conjugal choices specific to persons of immigrant descent? What are the criteria of mate selection? And why choose to form a mixed couple?

In our case, we decided to explore the various conjugal choices available to the children of immigrants of North African, Sahelian and Turkish origin. Three conjugal patterns were identified by the survey of immigrants' children to understand the factors that influence a particular marital choice over another. The study looked at the cultural, social and gender dimensions which reveal marital choices in different combinations for different individuals. This sets us apart from other sociologists who have studied mixed couples (comprising a member of the mainstream population and an immigrant or an immigrant's son or daughter). Their studies have analysed changes in the number of mixed couples, or the factors which favour mixed unions and the effects of such unions. But these studies generally do not consider the other possible conjugal options, for example by comparing individuals who decide to form a mixed union with those who do not. The main purpose of such research is to explore the factors which favour mixed unions, since in both qualitative and quantitative research the underlying assumption is that mixed couple formation is an indicator of integration. ${ }^{1}$ The approach is macro-social, linked to the conditions of "social harmony" 2 , whereas in our case, our concern is to understand how, among a range of possible conjugal options, this particular choice is made by the individuals concerned. For this reason, our empirical work is based on qualitative interviews tracing individual life event histories (we will return to this below).

Our approach is thus original not because it looks at mixed unions, but because it examines the conjugal choices of the second generation in relation to the range of other possible options (mixedness being one among several). Our aim is to study the conditions which make one choice possible rather than another, considering not only personal and familial trajectories but also social contexts. Before a couple is formed, there is a preliminary phase in which the individuals concerned are shaped by family values, and by personal experience in school, in the neighbourhood and with peers. It is during this period that the range of future conjugal options is progressively defined. We call it the preconjugal socialisation phase to highlight the fact that individuals are constrained in their conjugal choices both by a set of subjective experiences and by their objective social conditions. However, this phase does not determine all individuals in the same way: some are more receptive to the values promoted outside their own membership group, notably those of the mainstream society. The chosen conjugal option ultimately reveals the patterns of reasoning

1. The question of intermarriage was first theorised by researchers in the United States. Notably, the book by M. Gordon (1964) explicitly affirms the relationship between intermarriage and assimilation (see following note).

2. There is an abundant literature in the United States on this question since the 1920s. For example: Park and Burgess (1921), Merton (1941) and Gordon (1964), and more recently Perlmann and Waters (2007). For a literature review on this question see M. Safi (2008). 
that underlie this compromise between family expectations and more personal choices linked to individual experience. The concept of preconjugal socialisation enables us to address the factors affecting conjugal choice with particular focus, in the context of this article, on those who choose a mixed union. In other articles, a different approach has been adopted (Santelli, Collet, 2011a).

According to our specific analyses of data from the Trajectoires et Origines (TeO) survey (INED/INSEE, 2008), more than one third (39\%) of immigrant descendants (sons or daughter of parents who are both immigrants of the same country) of our target group choose a partner from the mainstream society, 22\% choose an immigrant descendant raised in France and 39\% marry an immigrant. These proportions are low compared to the earlier migration waves (Spanish, Italian, and Portuguese) and even compared to the Asian second generation ${ }^{3}$.

We will first address the specific way that couples are formed among descendants of immigrants from North Africa, Turkey and sub-Saharan Africa. In the second section, we will describe the methods applied and more precisely the population surveyed. The next two sections are devoted to our empirical data, first to describe how the conjugal choice emerges and then to analyse family dynamics, from the viewpoint of both couples and parents, and to determine what they transmit to their children.

\section{Second generation conjugal patterns: a specific mode of couple formation}

The question of conjugal patterns lies at the crossroads of the private and public domains and therefore allows us to see the transformations occurring in immigrant families due to their children's choice of spouse. Contrary to what takes place in the mainstream population, marriage in immigrant families is largely influenced by the extended family - marriage is very important, as is founding a family, and family members work actively to "find" the right spouse. Arranged marriages are still quite common in the countries of origin, despite a gradual decline (Kateb, 2008), and while sometimes still a subject of jokes, the role of matchmaker is still very much alive and still a prerogative of the women of the family. What's more, in the migratory context, this has become a "sign of belonging" (Neyrand, Hammouche, Mekboul, 2008). In the private sphere, the choice of spouse is undeniably embedded in a system of norms that puts the family first, and that is intended to guarantee the survival of a collective identity. Persons of immigrant descent must incorporate that reality.

At the same time, thanks to their socialisation in French society, they have grown up around friends who lived in a very different world and have had romantic relationships that conflicted with their family's expectations. This

3. Analyses are in progress and our statistical findings will be published in the next months (Collet, Santelli, 2012a). The proportions of mixed couples are lower than those found by the $\mathrm{TeO}$ survey (Hamel, et al, 2010), as we only consider individuals with two immigrant parents. 
is an interesting way of seeing the question because it gives an understanding of how persons of immigrant descent behave, not only with respect to their parents, but also with respect to other young people of their age. In the face of that double system of reference, which evolves over the years, what choices do the second generation make? How do they juggle between their parents' desires and their own aspirations? On a different level, the way these couples are formed tells us something about how they relate to society, and about the various worlds at their disposal. For the question of mate selection is intrinsically tied up with the forming of social universes. Depending on the residential context, school and occupational trajectories, the opportunities for meeting a partner are very different.

Following A. Girard's pioneering work (1964) that established social homogamy as the albeit unconscious guiding principle in mate selection, Bozon \& Héran's survey 25 years later made an important contribution. Aside from confirming the prevalence of homogamy, they stressed the importance of what they called the "social framework of sociability". "If a person doesn't marry just anybody, it's mainly because they don't go with just anybody and don't do so just anywhere" (Bozon, Héran, 2006: 12): that way of summing up the situation also applies to our population. We call that phase - which occurs before the conjugal choice but is closely connected to it- "pre-conjugal socialisation". The latter refers to the factors which come into play when a couple is formed, by looking at places of residence, school careers, and teenage love relationships, and how they tie in with the parents' normative identities and the new cultural identity asserted by the couple. We will return to this at length when presenting our empirical data.

So, as is often the case, analysing how a couple is formed is not limited to the relationship between two people: in the case of persons of immigrant descent, it means studying the way they relate to others, their affinities, likes and dislikes and, in the end, the compromise achieved between individual desires and family transmission. Thus, as in other research concerning the way couples are formed (Bozon, Héran, 1987) ${ }^{4}$, we must try to grasp the cultural and social orientations underlying the choices made by these descendents of immigrant parents, as they set out on their conjugal adventure.

\section{Methods and survey population}

In terms of method, we are interested in both the biographical approach and comparing three sorts of couples. Forming a couple is a phase in life that reveals how each partner manages his/her dual system of references, based on transmitted values and on social dynamics. In-depth biographical interviews are ideal for understanding this dual system, because they deliver a large

4. Other sociologists have studied social homogamy in France, including D. Merllié (2001) and F. de Singly (1987). Concerning the mainstream population, this is a standard approach for studying couple formation. 
amount of material to analyse how conjugal choices emerge from the "social framework of sociability" and how they combine with the other social dynamics that crop up along the way. Couple formation is seen as a historical process: one must look at what took place before, study each partner's situation, confront the various spheres of life in which each is immersed. Thinking out the conjugal itinerary means looking at all the levels of analysis, from the most micro level (self, family, friends...) to the most macro level (residential segregation, economic context...), through the "meso" or intermediate level (school, occupation, social life, etc.). Studying mate selection cannot be limited to noting the partner's characteristics, it involves following the road that led to the choice of one person over another, and considering all the factors that may have contributed to this choice.

It seems to us that the life-course method is the most appropriate. It involves in-depth interviews during which interviewees are asked to describe their trajectories, to develop a narrative through which they present their choices, their doubts, difficulties, aspirations, ways of life, and resources. From the wealth of information they contain, interviewee-interviewer interactions aim to extract the elements that seem to play a decisive role, but also the hidden or contradictory ones. This micro-sociological approach is then combined with what is known about the more macro-sociological phenomena.

Another characteristic of our approach consists in comparing the conjugal patterns revealed by our survey population, here reduced to three configurations based on the combined national origins of both partners. This allowed us to see how mate selection grew out of the internal and external factors that influenced their individual itineraries, taking different paths according to the following conjugal patterns:

- either two French citizens of immigrant descent whose parents came from the same geographical area;

- or a French citizen of immigrant descent and an immigrant from the parents' country of origin (met in France, or in the country of origin);

- or a French citizen of immigrant descent and a French citizen of nonimmigrant French descent, or whose parents belong to the earlier immigration immigrated from a European country (ex. Italie, Portugal, Spain).

According to the couples themselves, only the latter (one French citizen of immigrant descent and one French citizen of French non-immigrant descent) are considered as mixed. Yet, sociologically speaking, couples comprising one French citizen of immigrant descent, and one immigrant from the parents' country of origin could also qualify as mixed in both legal and social terms because the partners have different nationalities and were socialised in different national contexts. This shows how complex the notion is, but for the sake of our presentation, we will take the couple's definition for granted.

We studied women and men born and/or educated in France (since elementary school at least) whose parents both immigrated; we say they are "of 
immigrant descent". Overall, we carried out 91 in-depth biographical interviews with 57 women and 34 men.

All were young adults under 35, cohabiting (married or not) or having definite plans to settle down as a couple. Thus, either their life as a couple had already begun (they were already engaged, in love, or had started their conjugal "negotiations"), or were newly-weds or living together for at least five years.

Our fieldwork was carried out in Paris and Lyons, in two sorts of residential areas - mixed lower-middle-class neighbourhoods, on one hand, and so-called "disadvantaged" neighbourhoods, on the other- in order to observe the effects of the various sorts of social life, and consequently, of the different places people may meet.

Our sample included persons connected to immigrant groups from three geographical zones: North Africa, Turkey and Sahelian Africa. 57 descendents (two-thirds of the population) have parents who emigrated from one of the North African countries (Algeria, Tunisia, Morocco), 14 have parents from Turkey and 20 have parents from a the French-speaking Sahelian African country (Mali, Mauritania, Senegal, Guinea). In these countries of origin, marriage is universal ${ }^{5}$ and family relations are based on a patriarchal model.

Though each national group possesses cultural particularities and has a specific relationship with France and its migratory history, they are similar to the fact that they have Muslim culture and/or religion. These populations also share similar experiences as to place of residence in France and are exposed to similar forms of discrimination (in access to employment, housing or leisure activities), and their fathers occupy, or occupied, mainly unskilled or lowskilled occupations.

\section{The process of conjugal choice}

Focusing on pre-conjugal socialisation provides insight into the union formation process: how do individuals choose between different possible options? what are their most cherished aspirations (a shared social and/or cultural universe)? all in all, which affinities prevail? The aim is to explore the processes that precede and may in fact determine this conjugal choice, rather than concentrating solely on the spouses' social characteristics.

Biographical surveys show how these choices were made. Four factors seem particularly influential: the residential environment, schooling, family education, friends and meeting places. They constitute what we call pre-conjugal socialisation. We were therefore able to define a set of criteria that favour the formation of mixed couples. However, none of these factors has any mechanical effect in itself: the life-course approach allows to see how they combine, and what they produce in each case.

5. The celibacy rate is very low and non-marital cohabitation is strongly condemned, as is any form of sexuality outside marriage. 
During the pre-conjugal socialisation phase, what we see is a combination of family values - especially their expectations in matrimonial affairs - and personal experience. Personal experience is the fruit of the structural framework in which the individuals were raised, depending on residential characteristics and family context, their contacts with peers, and their own aspirations. These aspirations develop with reference to the education received in the family that either created a world of possibilities, or led to a reinterpretation of its educational heritage, or even to a rejection of this heritage. These aspirations develop also with reference to desires born of individuals' multiple experiences, of the relational and institutional circles in which they have moved (peer groups, schools, value promoted in these social environments, etc.). The relationship between the various contexts of their pre-conjugal socialisation is dialectical and continuous.

\section{Residential diversity versus spatial segregation}

Residential environments can be defined in terms of the social and cultural diversity of their inhabitants. As we have no data about the ethnic diversity of the neighbourhood, we consider the way individuals spoke ${ }^{6}$ of the place and what that showed about "the social processes triggered when groups coexist" (Collet, Philippe, 2008). While some young adults reported living in an HLM (low-rent housing) "like in a ghetto", others stressed mainly the aspect of "mixing, being open to diversity" (i.e. diverse origins). They thus created radically different frames of reference whose effects are clearly visible if one looks at the practices inside and outside the family. From the composition of the neighbourhood, which directly affects the composition of the peer groups inside and outside school, to the chances of accessing different social spheres (sports, culture, associations, politics...), the place of residence affects the likelihood that these young people will make friends and acquaintances in the mainstream group.

There were Portuguese, Turks, Moroccans, Algerians, Tunisians, French, Italians, we were all mixed up (...) we stuck together like one big family, we had lots of activities, we all played together, we didn't care who was who [later, when she was 7 , her parents bought an apartment in the centre of town]. It's true that that helped too, we were even more open, we saw different sorts of people (...) We played a lot of sports, because in Savoy there's a lot of open spaces, lots of stadiums, so we really got into sports. (woman, age 27, Moroccan origin, grew up in a small town in the Savoy, tri-lingual secretarial qualification, executive assistant, in a relationship with a man of Caribbean origin for the last year).

Some of the families due to circumstances, or because they wanted to avoid the poor suburbs, ended up in a "mixed neighbourhood" (often an old, innercity quarter). Such parents may have clearly encouraged the tendency to "live

6. We recorded above all the subjective perception of diversity. In reality, however, the two extremes form the two ends of a continuum of situations. 
like the French". In segregated suburbs, though, parents visibly develop very different attitudes, with some being in favour of "going with the French", some tolerating it or showing certain wariness, and others forbidding it entirely. This doubtless leaves a mark, for in any case, the socialisation process makes it clear to young people what is and is not possible in terms of affinities and relationships.

I'd always been somewhat cosmopolitan in my head, since I was little (...) my father wanted us to go with the French because he wanted us to be cultured. (woman, age 35, Moroccan origin, grew up in a small town in the Loire, philosophy post-graduate teaching qualification, teacher, married, French husband).

When the parents have an open attitude, the youngsters are more inclined to experiment with diverse and extreme types of social life where the "French" are in the majority. Undeniably, in that case, the fact of having first been in touch with a social environment qualified as "French" seems to favour the formation of a mixed couple - although this is a necessary but far from sufficient condition. Conversely, however, without such an environment, the probability of creating a mixed couple is very low. Indeed, to be able to even imagine such a thing, these youngsters must have been able to frequent "French youngsters with French parents" or other descendants of older immigrant groups; they must have had the chance to see how these other youngsters live their daily lives, to experience situations allowing them to become familiar and feel at home with them.

Those who always lived in very segregated places can't even imagine forming a mixed couple: their conjugal choices are necessarily more endogamous. Research on poor suburban neighbourhoods has established the relation between interethnic marriages and social segregation (Peach, 1980; Blau et al., 1982). The more segregated a housing area, the less interethnic contacts it offers and the lower the number of mixed couples. M. Safi (2008) found a similar phenomenon in France. In different terms, maintaining minority status and the stigmatisation that goes along with it, being obliged to live in segregated urban areas - banlieues in France - and the inequality and injustice experienced by non-white and/or Muslim populations contributes to the formation of an ethnic marriage market (Kalmijn, 1998). Since forming a couple is the extension of other forms of social relationship initiated as children (making friends, flirting, etc.), it expresses the degree of opportunity to meet different people depending on the places where they socialize.

The itinerary at the heart of the residential framework has to be explored in relation to the school and family contexts that either strengthen or weaken the sense of having lived in a mixed neighbourhood or a ghetto.

\section{Educational trajectories that strengthen the residential effect}

When the residential context exhibits a relative mixing of populations (socially and culturally), the school context usually does too, promoting mixed social 
networks and in the long term the possibility of mixed couples. Young people who grow up in segregated neighbourhoods may also have access to that sort of school context if they attend a school in the centre of town and then go on to higher education. In that way, they penetrate a new social universe with norms, practices and values different from that of their family and from the residential context in which they were raised. In such institutions they find themselves in the minority — either because they have entered a more "elitist" school or course, or because they have started university - and feel the difference keenly, even painfully (Santelli, 2007a). If they manage to overcome that hurdle, the fact that they have mastered their new environment broadens their horizon of possibilities. That change also has consequences in terms of mate selection. The higher the educational level, the more a person aspires to choosing his/her spouse freely, which is also the case in the countries of origin (Kateb, 2008). This choice is made on the basis of affinities which necessarily include social dimensions (linked to a similar level of education, a similar professional universe, a similar social status, a similar lifestyle, etc.). The quest for social homogamy can now take precedence over cultural preference, or be combined with an endogamous choice. Aside from mixed social networks and the variety of social territories experienced, a higher level of education also results in weaker adherence to parental norms, especially when it is also associated with professional stability and upward mobility. More mixed couples are formed when residential and school contexts favour making friends and being intimate with the mainstream group from early childhood.

\section{Education in the family}

The code of conduct expected of or even imposed upon the daughters of immigrants is clearly different to what is expected of other girls of their age. First, the family atmosphere may not be conducive to talking, especially about the body and sexuality, and second, sons and daughters are expected to behave very differently. Girls don't have the same rights: they must do housework, their movements are supervised, sometimes very strictly, their sexuality is controlled, along with any behaviour that might reveal "depraved habits" such as smoking, drinking, going with boys, going out at night, wearing mini-skirts, etc. (Harrami, 2008). Young women of immigrant descent are confronted by two diametrically opposite sets of norms, torn between the respect they feel for their parents' wishes, and their desire to live more freely, like other girls. Faced with these constraints, they internalize also the fact that a mixed conjugal choice would never be accepted by their family.

For this reason, despite a few experiences, many of them give up, preferring to break off a relationship rather than risk a conflict with their parents. What's more, when going out is strictly controlled and girls have a hard time asserting themselves (going out at night, wearing certain clothes, having a sex life...), giving priority to a boyfriend of the same origin (assumed to be more understanding) seems an obvious choice. 
However, this observation has to be qualified by the fact that families have quite different ways of life; some of them treat their daughters and sons more equally than others, permitting certain behaviours - being more tolerant about the girls' going out or who they go with, for example- which provides opportunities for different conjugal choices. Several factors favouring such open attitudes have been identified, such as the father's level of education and occupational status and, even more so, the mother's occupational status. Beyond the mother's actual occupation, being in employment means a second source of income, exposure to colleagues, accessing other aspects of French society, etc. When mothers are in wage employment, the attitude towards French society is so open that it often also transforms their relationship with their own husband and produces very visible consequences for the children's education: greater freedom of action and movement for the girls, fewer privileges for the boys. Mixed couples then become more frequent.

A second factor is freedom of speech in the family, when no subject is taboo, including love relationships and sex, at least among some members of the family. In families which care about each other's well-being, which aim for equality among the members and choose to stay in France and participate in the society, the parents aim to achieve better understanding in the family; sometimes this was already part of the family's make-up at the start. Though mixed couples are rarely accepted without hesitation, they are much more easily adopted by such families. We must not forget, however, that a difference between men and women - justified for religious reasons - still remains, but isn't resistance to mixed marriage a typical reaction of all groups?

Thirdly, if the parents divorce, and a new family is formed, that clearly affects the children's possibilities for other conjugal choices. In this case, this reflects not so much an attitude of openness to the lifestyles of the mainstream groups as a lesser cultural transmission within the family and fewer demands on the marital front. This is especially true if the parent with custody of the children (the mother) has made a new life for herself in France by openly defying the matrimonial traditions inherited from the country of origin.

Since what happened between my parents - I think that's where it comes from - I've been very, very reticent about black men. (...) I always choose my own boyfriends, when things go wrong you can't say 'it's your fault' [her mother's fault], because that's what my mother went through with my father (...) she knows how much it hurts and I think that if only for that reason, she didn't want to do the same thing to us [choose their spouse for them].

(woman age 28, Senegalese origin, grew up in the Paris region, qualified community social worker, French husband)

In the last analysis, events often beyond a person's control create biographical turning-points ${ }^{7}$ that turn out to be decisive in their life course. For

7. These are changes which radically alter the course of existence, not necessarily negatively or dramatically but nevertheless creating a profound change at a precise moment, so that there is a "before" and an "after" (Hareven, Masaoka, 1988). 
instance, educational or career choices may take people far away from their home and "community". But it is especially family events such as the parents' separation - the children then usually live with their mother- death (usually the father's), his declining authority for whatever cause (illness, old age, alcoholism, etc.), which remain most significant. The father's absence (whether real or symbolic) appears to be a crucial factor, with powerful effects on the future choice of spouse: forming a mixed couple is more likely when the father is "absent".

\section{Social life and meeting the future mate}

The three preceding points show how varied the personal itineraries of these young people are: they have not lived in the same contexts or experienced the same things. As a result, the opportunities to meet a future partner are very variable too, and more or less conducive to forming mixed couples. Broadly speaking, "diversity" - i.e. the mixing of populations of diverse social and cultural origins in different spheres of social life-clearly orients mate selection, above and beyond the parents' specific normative expectations. So when young people have the opportunity to socialize at school, in the neighbourhood, sports or cultural activities, and to have mixed social relations, the chances of meeting a "French girl or boy" are more frequent and seem more "natural". They acquire experience of romantic relationships during adolescence. When they have been involved in these networks and have experienced mixed relationships (as boy and girlfriend), mixed couples are taken for granted.

Another powerful factor of distinction for girls of immigrant descent is the virginity rule. Breaking the taboo of staying a virgin until marriage determines the way they relate to conjugality. By losing their virginity, these girls are acting like the other girls of their generation. Asserting such a choice, which represents a total break with the expected family norm, points to their preference for a French partner, and hence for becoming part of a mixed couple. Rising above such a prohibition commits them over the long term and marks their intention to distance themselves from the family environment. Overall, such a choice reflects their refusal to live according to certain prescriptions and references that seem "of another age", too far removed from the dominant model of the society to which they feel they belong.

I've always been a renegade (...) I wanted to be independent, I rented a small apartment near my mother's [from then on, she was able to partly live with a partner] (...) I finally decided to become really independent when I moved into a one-room flat in Lyons [shortly after, she met her future husband]".

(woman, age 35, Moroccan origin, grew up in a small town in the Loire, Philosophy post-graduate teaching qualification, teacher, married, French husband)

The geographical and life experiences of young adults tend to structure differently the places where a partner can be met. In mixed couples, the future partner 
was often part of the group of friends, or they met at work, university or in a public place like a discotheque or a train station. Friends seem to be the main vectors, their networks being mixed or largely French. Their itineraries prior to meeting their partner show that very different "conjugal possibilities" exist.

Once the future partner has been met, and the couple formed, we note that, like the great majority of couples in the general population, they decide to cohabit without marrying, only later deciding to marry — or not. In the general population of France, living together out of wedlock has become the main way of starting out as a couple: $90 \%$ of all new couples today form a non-marital union, compared with just 10\% in 1965 (Daguet, 1996).

For mixed couples, the three phases - having sex relations, forming a couple and marrying - are radically disjoined, whereas among endogamous couples the three stages are synchronized, with marriage being the pre-condition for starting life as a couple and sexual activity; and before marriage a series of rules must be followed (asking for the woman's hand, staying a virgin, etc.) ${ }^{8}$. Aside from the love that unites them (which, unlike the parents' generation, is the same for endogamous couples); the partners in a mixed couple have the opportunity to experiment with different forms of conjugal life before becoming "official".

But that way of doing things does not conform to the matrimonial practices of the group to which they belong, and the parents react in one of two ways. They may refuse to recognize the couple, which can end in conflict, and break off relations with the family (usually only temporarily). This is more often the case where the woman is concerned. It is more difficult for a woman than for a man in a mixed couple to obtain parental acknowledgement of the union. The tensions, misunderstandings, and discord are such that sometimes the young woman must leave her parents' home secretly (when the parents are out). Often, the birth of grandchildren provides an opportunity for reconciliation.

Alternatively, the parents may have ambivalent feelings but they accept the union for the sake of their children's happiness and to preserve family unity. This is particularly the case when a son is involved. In every case, the parents try to conceal the mixed union from the rest of the family and the neighbours, which means that the spouse does not participate, for example, in certain family reunions. To obtain their parents' approval and be more accepted by the entourage, the future spouse must often consent to convert to Islam (at least for appearances' sake) and the couple must do their Fatiha.

\section{Family dynamics}

Once they are in place, how do these couples function, in particular as regards their domestic organisation? Women's labour force participation is of key importance for mixed couples, as it is in the national population and among most endogamous couples likewise; women say they intend to work. Most

8. Cf. our article on this question (Santelli, Collet, 2011b). 
are economically active and consequently demand greater equality in each partner's contribution to the domestic sphere.

\section{The couple}

While the partners do not assume equal responsibility for the various chores, there is negotiation and sharing, chores are distributed according to each partner's schedule and obligations. In that, these couples' behaviour conforms to the dominant norm of more equal division of parenting and domestic tasks: the women expect their partner to be more involved in the household. Talking and negotiating are two essential vectors of the aspiration to greater gender equality in the couple.

More generally, for these couples based on affinity and love, the idea of individual self-fulfilment by and through the couple is omnipresent. That is why they give priority to a lifestyle that leaves room for friends, outings and leisure. In their social life, a shift is observed towards the network of friends and away from the family, especially when there are tensions. These couples are more individualistic and tend to remain on the margins of the family or give preference to the side where relations are better.

Mixed couples thus often mark their distance from the family universe, asserting their desire to live according to their own references and tastes, and refusing to follow an inherited model and a way of life dictated by tradition. They usually say they have broken with their cultural heritage, religion in particular (some declare they are atheists), though there are gender differences.

Of course, the individuals do maintain relations with their parents, and even value them, but they dissociate the two aspects of their social life: on one side, they behave the way their parents expect them to, when they go to visit, while on the other, they behave and do things according to the aspirations that guide their daily life. "Living with a French woman" allows the men to lead the life that they want to lead and share it with their wife. They are capable of changing their cultural references according to the cultural and social context. The way both realities coexist, without creating any internal conflict, reminds us of the "duality principle" developed by R. Bastide and F. Fernandes (1955).

It was obvious that a gap was widening with our parents over religion; it no longer meant anything to me, but still it was always present [in the family] and that's something I could never tell my parents [like the fact he does not observe the Ramadan and does not believe in God] (...) In my parents' home there are still taboos [whereas] at her parents' home, I can let myself go. I can drink, I can joke, talk about everything, there are no forbidden words".

(man, age 32, Moroccan origin, grew up in the Paris region, baccalaureate, training to become a special education teacher, informal union, partner of French origin).

For the women, the motivations are the same, but they also express a greater desire to "keep up certain things", to maintain their "double culture". 
They seem to be more in-between: their exogamous choice corresponds to their desired lifestyle, since they feel more "free" and self-fulfilled than if they were with a man of the same origin, but they do not want to break with their cultural and family origins.

I felt freer with someone French (...). [With men of Maghrebi origin] I always had to fight to get the things that seemed obvious and normal to me (...) it was such a problem that I was afraid for the future (...) I had to hide a whole part of my life.

(woman, age 35, Moroccan origin, grew up in a small town in the Loire, Philosophy post-graduate teaching qualification, teacher, married, French husband)

In the couples where the woman is of Muslim and the man of French culture, generally more secularized than his wife, he frequently wants to limit the cultural and religious practices at home. Forming a "mixed couple" may be a woman's way of expressing her desire to break with her original cultural background, which does not necessarily mean breaking with her family, but with the rules and norms judged to be archaic. The choice of mate from a different origin distances the woman from the inherited culture that she is supposed to perpetuate. The women know they risk their family's disapproval, or even anger, and for that reason are perhaps even more inclined to adopt their husband's family culture. But at the same time, once they have started the process, they have no choice but to continue, since changing their course would mean a conflict with the spouse. In this sense, mate selection is the consequence of a process of reflection that leads women to distance themselves from a cultural system that does not correspond to their lifestyle, in favour of that of the majority group.

\section{Cultural transmission to the children}

The choice of first names, for instance is very significant. Symbolically, it signifies registering the child in one system rather than the other (Santelli, Collet, 2003), while serving as a visible message to the rest of society. Among couples where both partners share the same origin, as well as among mixed couples, we note that the parents are careful to give a "first name that does not have particular connotations, and sounds cosmopolitan", that are "acceptable" anywhere. Doing so represents the desire to avoid stigmatizing the children. First names are negotiated, because both partners want to be able to identify with them: they have to be pronounced easily and be not too culturally specific, which is why classical names such as Marie or Fatima are rejected. On the contrary, cosmopolitan or rare names are preferred: Medhi, Yanis, Ilan, Izak, for boys, Inès, Anissa, Nina, Yasmine, for girls.

Concerning transmission of an ethnic identity different patterns occur according to the intensity parents stick to the ethnic belonging of the immigrant descendant (Saenz et al., 1995). Since French is usually the parents' 
only tongue, transmitting a "language of origin" (Santelli, 2007b) is almost impossible. The parents sometimes say they would like their children to speak the grand-parents' mother tongue and count on them for that, but this rarely happens in practice. When neither parent practices a religion (usually the case of mixed couples) they decide not to transmit a religion or any religiously connoted cultural practices. They opt for the solution of answering the children's questions but letting them "choose later".

However, non-Muslim women usually seem in favour of circumcision, saying it puts the boy into line with the father, and that it's more hygienic. But when the man does not belong to a Muslim culture, some refuse to let their sons be "mutilated", adding it would reduce his sexual pleasure. Generally speaking, women seem to go along with their husband's culture more readily, and it becomes the couple's dominant culture. French women are more likely to transmit the cultural values of their Maghrebi husband than the other way around, as if women were readier to adopt the other's culture ${ }^{9}$. Some even take classes to learn Arabic or Berber. In the same vein, they are more willing to choose a first name identified with the man's culture.

\section{By way of conclusion}

At the end of our survey, it seems that in order to understand the behaviour of mixed couples, we must study them using the life-course approach, and compare them to non-mixed (endogamous) couples. This narrative-based sociology allows us to grasp, beyond objective variables, how a couple comes to terms with the various constraints, aspirations and resources.

However, it is important to remember that mixed couples are not formed at random: a whole set of events during the pre-conjugal socialisation phase combine to explain this type of mate selection. Neither is the temporal dimension a sufficient explanation, as if with time one should inevitably observe an increase in the number of mixed couples. The biographical nature of our investigation allowed us to reveal the complexity of the familial and social origins of these marital choices. By placing them in context, we became aware of the connection between a private event (mate selection) and decisive economic and social influences, often summed up in the term "social diversity". Residential, school, and occupational itineraries, and relations with peers reflect that social mixture or its opposite, segregation.

Indeed, the $\mathrm{TeO}$ survey data suggest that the youngest cohorts are less likely to form mixed couples, as their existence implies that certain social conditions are satisfied. In this sense, conjugality thus resembles a laboratory. Other researchers before us have already highlighted this fact (Safi, 2008; Muttarak, 2010). But here, the aim is not so much to point out that individuals juggle with different cultural references, but rather to say that their conjugal

9. Saenz et al. (1995) mention this fact, some studies observe a gender difference in transmitting culture, others not. 
choices shed light on the state of social interactions and of social tensions in different spheres of social life (in school, in segregated neighbourhoods, at the time of educational choices, through the opportunities to meet individuals from different social origins, etc.). The fact that there are more endogamous couples than mixed couples among the populations we have studied (Collet, Santelli, 2012a) reflects the existence of particular social conditions, made visible through their life event histories.

That is why the results of this study lead us to hypothesize that young people of immigrant descent do make endogamous choices, but this endogamy is reinterpreted. Their endogamous choice of spouse testifies to the realities with which they are confronted. Reinterpreted endogamy, as observed among the young couples, borrows from the cultural traditions while pointing up the persistence of social exclusion:

- the endogamous choice constitutes a form of protection in the face of increasingly blatant segregation in the poor suburbs of French cities;

- it may also be connected to experience of discrimination (in leisure activities, employment, housing, school ...) ;

- it also testifies to the difficulty on both sides, of acknowledging (and experiencing) the multicultural dimension of society: discriminating effects on one side, repeated experiences of racism, rejection, and unequal treatments on the other, create a preference for staying with one's "own kind". In this sense, the difficulty is also an obvious sign that integration policies in France have failed.

However, whether couples are endogamous or mixed, our research reveals that these young couples have broken with their parents' generation while conforming to society at large. Like the other young people of their generation, they adopt the values that become meaningful with relation to their specific social conditions. Processes of individualisation are perceptible in the way they set up their couple and then try to gain their parents' acceptance, and this process intensifies once the new family unit has been established. Women and men negotiate their work and family choices together, naturally prey to gender and class conflicts - as is the case for the other individuals of their generation.

\section{Bibliographic references}

BARBARA, Augustin (1985). Mariages sans frontières, Paris: Le Centurion.

BASTIDE, Roger \& FERNANDES, Florestan (1955). Relaçoes raciais entre negros e bancos em São Paulo. São Paulo: Anhembi.

Blau, Peter M.; Blum, Terry C. \& SChWartz, Joseph E. (1982). «Heterogeneity and intermarriage». American Sociological Review, 47, 45-62.

Bozon, Michel \& Heran, François (1987). «La découverte du conjoint». Population, 6, 943-985 and 1, 1988, 121-149.

BozOn, Michel \& HeRAN, François (2006). La formation du couple. Paris: La Découverte. 
Collet, Beate (2010). «Pluralité contemporaine de la mixité conjugale et position asymétrique entre les sexes». Diasporas. Histoire et Société, 15, 53-67.

Collet, Beate (1998). «Intégration et mixogamie en France et en Allemagne». En: Philippe, Claudine; Varro, Gabrielle \& Neyrand Gérard (eds.), Liberté, Egalité, mixité... conjugale. Une sociologie du couple mixte. Paris: Anthropos, 139-171.

Collet, Beate (1996). Citoyennetés et mariage mixte en France et en Allemagne. Doctorat de sociologie, EHESS, Paris.

Collet, Beate \& PHilippe, Claudine (2008). "Parcours réflexif et tentative conceptuelle». En: Collet, Beate \& Philippe, Claudine (eds.). MixitéS. Variations autour d'une notion transversale, Paris: L'Harmattan, 219-246.

COllet, Beate \& REgnARD, Corinne (2011). «La réalité socio-culturelle de la mixité franco-étrangère. Analyse de données statistiques d'une enquête auprès de primoarrivants». Revue européenne des migrations internationales (forthcoming).

Collet, Beate \& SANTElli, Emmanuelle (2012a). «Les descendants d'immigrés en couple mixte au prisme de l'enquête. Trajectoires et Origines». Enfance, Famille, Génération, 2012 (forthcoming).

Collet, Beate \& SANTElli, Emmanuelle (2012b). L'entre-soi conjugal. Etudier les conjugalités des descendants d'immigrés. Paris: Presses universitaires de France (forthcoming).

Collet, Beate \& SANTELli, Emmanuelle (2008). "La mixité au-delà des différences culturelles. Les choix conjugaux des descendants d'immigrés maghrébins». In: Collet, Beate \& Philippe, Claudine (eds.). MixitéS. Variations autour d'une notion transversale, Paris: L'Harmattan, 69-93.

Daguet, Fabienne (1996). «Mariage, Divorce et union libre». Insee Première, 482, 1-4.

Delcroix, Catherine; Guyaux, Anne \& Rodriguez, Evangelina (1992). Double mixte, la rencontre de deux cultures dans le mariage. Bruxelles: Contradictions/ L'Harmattan, ADRI.

FILHON, Alexandra \& VARro, Gabrielle (2005). «Les couples mixtes. Une catégorie hétérogène». In: LEFEVRE, Cécile \& FILHON, Alexandra (eds.). Histoires de familles, histoires familiales. Paris: INED, 483-504.

GIRARD, Alain (1964). Le choix du conjoint. Une enquête psycho-sociologique en France. Paris: INED-PUF.

Gordon, Milton M. (1964). Assimilation in American Life: The Role of Race, Religion and National Origins. New York: Oxford University Press.

Hamel, Christelle; Lhommeau, Bertrand; Pailhé, Arianen \& Santelli, Emmanuelle (2010). "La formation du couple entre ici et là-bas». In: BEAUCHEMIN, Cris; Hamel, Christelle \& Simon, Patrick (eds.). Trajectoires et Origines. Enquête sur la diversité des populations en France, premiers résultats. Documents de travail 168, INED, 85-93.

Hammouche, Abdelhafid (1990). "Choix du conjoint, relations familiales et intégration sociale chez les jeunes Maghrébins». Revue Européenne des Migrations Internationales, 6 (1), 175-187.

Hareven, Tamara K. \& MAsaOKA, Kanji (1988). «Turning points and transitions: perceptions of the life course». Journal of Family History, 13 (3), 271-289.

HARRAMI, Nourredine (2008). «Les filles des migrants marocains en France et les règles familiales relatives à la chasteté de la jeune fille». In: MELliTI, Imed; MAHFOUDH; Draoui, Dorra; Ben Amor, Ridha \& Ben Fredj, Slaheddine (eds.). Jeunes, dynamiques identitaires et frontières culturelles. Tunis: UNICEF, 237-251. 
Kalmijn, Matthijs (1998). "Intermarriage and homogamy: causes, patterns and trends». Annual Review Sociology, 24, 395-421.

KateB, Kamel (2008). "Du mariage précoce au mariage tardif dans les pays du Maghreb, quels enjeux de société ? Scolarisation et évolution des rapports de genre». Communication au colloque international de Québec, Démographie et culture, Aidelf, 25-29 août 2008.

LE GALL, Josiane (2003). Transmission identitaire et mariages mixtes. Recension des écrits. Document de travail du Groupe de Recherche Ethnicité et Société du Centre d'Etudes Ethniques de Montréal.

Meintel, Deirdre (2002). «Transmitting Pluralism: Mixed unions in Montréal». Canadian Ethnic Studies, XXXIV (3), 90-120.

Merllié, Dominique (2001). «La mobilité sociale differe-t-elle selon le sexe?». In: Bloss, Thierry (eds.), La dialectique des rapports hommes-femmes, Paris: Presses universitaires de France, 151-173.

Merton, Robert, K. (1941). «Intermarriage and the Social Structure». Psychiatry, 4, 361-374.

Muñoz-PÉrez, Franscico \& Tribalat, Michèle (1984). «Mariages d'étrangers et mariages mixtes en France. Evolution depuis la première guerre». Population, 3, 427-462.

MUTTARAK, Raya (2010). «Explaining trends and patterns of immigrants' partner choice in Britain». Zeitschrift für Familienforschung/Journal of Family Research, 22 (1), 37-64.

Neyrand, Gérard; Hammouche, Abdelhafid \& Mekboul, Sarah (2008). Les mariages forcés. Conflits culturels et réponses sociales. Paris: La Découverte.

Neyrand, Gérard \& M'Sili, Marine (1997). «Les couples mixtes dans la France contemporaine: mariage, acquisition de la nationalité française et divorce». Рориlation, 52 (3), 571-606.

PARK, Robert E. \& BURGESS, Ernest W. (1921). Introduction to the Science of Sociology. Chicago: University of Chicago Press.

PEACH, Ceri (1980). "Ethnic segregation and intermarriage». Annals of the Association of American Geographers, 70 (3), 371-381.

Perlmann, Joel \& WATERS, Mary C. (2007). «Intermarriage and multiple identities». In: Waters, Mary C. \& UedA, Reed (eds.). The New Americans. A Guide to Immigration since 1965, 110-123.

Philippe, Claudine \& Collet, Beate (2008). MixitéS. Variations autour d'une notion transversale. Paris: L'Harmattan.

Philippe, Claudine; Varro, Gabrielle \& NeYrand, Gérard (1998). Liberté, Egalité, Mixité... conjugales. Une sociologie du couple mixte. Paris : Anthropos.

Rodriguez-Garcia, Dan (2006). "Mixed Marriages and Transnational Families in the Intercultural Context: a case study of African-Spanish couples in Catalonia». Journal of Ethnic and Migration Studies, 32 (3), 403-433.

Rude-ANTOINE, Edwige (1990). Le mariage maghrébin en France. Paris: Karthala.

SAD SAOUD, Hassina (1985). "Le choix du conjoint : tradition et changement». Revue Européenne des Migrations Internationales, 1 (2), 118-130.

SaenZ, Rogelio; Hwang, Sean-Shong; Aguirre, Benigno E. \& Anderson, Robert N. (1995). «Persistence and Change in Asian Identity among Children of Intermarried Couples». Sociological Perspectives, 38 (2), 175-194.

SAFI, Mirna (2008). "Inter-mariage et integration : les disparités des taux d'exogamie des immigrés en France». Population, 63 (2), 267-298. 
Santelli, Emmanuelle (2007a). Grandir en banlieue. Parcours et devenir de jeunes Français d'origine maghrébine, Paris: CIEMI.

SANTElli, Emmanuelle avec la collaboration de LAVASTRE, A. et MASSIP, M. (2007b). «Familles d'origine maghrébine et orthophonie : le vécu de la prise en charge». In: TAIN, Laurence (ed.). Langage, genre, profession : le métier d'orthophoniste. Rennes: Editions Ecole nationale de la santé publique.

SANTELli, Emmanuelle \& COLlET, Beate (2003). "Comment repenser les mixités conjugales aujourd'hui ? Modes de formation des couples et dynamiques conjugales d'une population française d'origine maghrébine». Revue européenne des migrations internationales, 19 (1), 51-79.

SANTELli, Emmanuelle \& COllet, Beate (2011a). "De l'endogamie à l'homogamie socio-ethnique. Réinterprétations normatives et réalités conjugales des descendants d'immigrés maghrébins, turcs et africains sub-sahariens». Sociologie et Sociétés (forthcoming).

SANTElli, Emmanuelle \& Collet, Beate (2011b). «Le mariage «halal». Réinterprétation des rites du mariage arabo-musulman dans le contexte post-migratoire français». Recherches familiales (forthcoming).

SHAW, Alison (2001). «Kinship, Cultural Preference and Immigration: Consanguineous Marriage Among British Pakistanis». Journal of the Royal Anthropological Institute, 7(2), 315-334

SinGLY, de François (1987). «Théorie critique de l'homogamie». L'Année sociologique, 37, 181-205.

Strassburger, Gaby (2003). Heiratsverhalten und Partnerwahl im Einwanderungskontext. Würzburg: Ergon Verlag.

STREIFF-FENART, Jocelyne (1989). Les couples franco-maghrébins en France. Paris: L'Harmattan.

STREIFF-FENART, Jocelyne (1985). «Le mariage : un moment de vérité de l'immigration familiale maghrébine». Revue Européenne des Migrations Internationales, 1 (2), 131-143.

Tribalat, Michèle avec la participation de SimOn, Patrick et Riandey, Benoît (1996). De l'immigration à l'assimilation. Enquête sur les populations d'origine étrangère en France. Paris: La Découverte.

VArro, Gabrielle (2003). Sociologie de la mixité. Paris: Belin. 